\title{
Estimation of Selected Minerals in Aortic Aneurysms - Impaired Ratio of Zinc to Lead May Predispose?
}

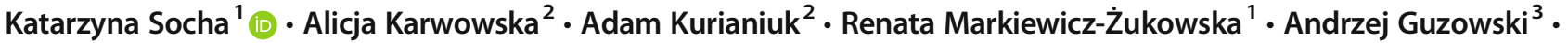 \\ Marek Gacko $^{3}$ - Tomasz Hirnle ${ }^{4}$ Maria H. Borawska ${ }^{1}$
}

Received: 14 August 2020 / Accepted: 23 September 2020 / Published online: 1 October 2020

(C) The Author(s) 2020

\begin{abstract}
The objective of this study was to estimate the content of copper, zinc, selenium, cadmium, and lead in the tissue of patients with aortic aneurysms. Molar ratio of $\mathrm{Cu} / \mathrm{Zn}$ and antioxidant micronutrients to toxic elements was also calculated. A total of 108 patients: 47 with abdominal aortic aneurysm (AAA), 61 patients with thoracic aortic aneurysm (TAA), and a control group of 20 abdominal aortic (AA) and 20 thoracic aortic (TA) wall samples from the deceased were studied. The concentrations of mineral components in the tissue samples were determined by the AAS method. The average concentration of $\mathrm{Cu}$ in the aortic wall of patients with TAA was significantly lower than in the aortic wall samples of healthy people. The mean concentration of $\mathrm{Zn}$ in the aortic wall of patients with AAA and TAA was significantly lower than in the control group samples. Cu/Zn ratio was significantly higher in AAA patients than in control group which indicates a greater role of oxidative stress and inflammatory process in this type of aneurysm. The concentration of Se was significantly decreased in TAA patients compared with the control group; in turn, the concentration of $\mathrm{Pb}$ was increased in this group of patients. We observed significantly lower $\mathrm{Cu} / \mathrm{Pb}$ ratio in TAA patients than in control group, whereas $\mathrm{Zn} / \mathrm{Pb}$ ratio was significantly lower comparing with control samples in both types of aneurysms. In the examined aneurysms, we have shown the differences in concentrations of mineral components compared with the control tissues. The $\mathrm{Zn}$ concentration was decreased in both AAA and TAA samples. Impaired ratio of $\mathrm{Zn}$ to $\mathrm{Pb}$ may predispose to aortic aneurysms.
\end{abstract}

Keywords Aortic aneurysm $\cdot$ Copper $\cdot$ Zinc $\cdot$ Selenium $\cdot$ Cadmium $\cdot$ Lead

\section{Introduction}

An aneurysm is an excessive increase in the diameter of an artery caused by weakening of the arterial wall, resulting in an abnormally large bulge. Aneurysms may remain asymptomatic or rupture, causing serious health problems and even death [1]. The aorta is the largest blood vessel in the body and is a common site for arterial aneurysms. Aneurysms in

Katarzyna Socha

katarzyna.socha@umb.edu.pl

1 Department of Bromatology, Medical University of Bialystok, Bialystok, Poland

2 Department of Hygiene, Epidemiology and Metabolic Disorders, Medical University of Bialystok, Bialystok, Poland

3 Department of Vascular Surgery and Transplantation, Medical University of Bialystok, Bialystok, Poland

4 Department of Cardiosurgery, Medical University of Bialystok, Bialystok, Poland the chest area are called thoracic aortic aneurysms (TAA). Abdominal aortic aneurysms (AAA) are the most common type. AAA is diagnosed in $1.4 \%$ of people aged between 50 and 84, 5.7 times more frequently in men than in women. The incidence of AAA increases with age [2]. In rare cases, damage to the arteries can affect both the chest and abdomen. The pathogenesis of aneurysm formation and rupture is not yet fully understood. Although the exact cause of an aneurysm is unclear, certain factors contribute to the condition. It is considered that damaged tissue in the arteries can play a role in the pathogenesis. Atherosclerotic disease, high blood pressure, inflammation, and infection can predispose to the formation of aneurysm. The vast majority of AAA is atherosclerotic. In contrast, aneurysms affecting the thoracic aorta (TA) are usually caused by medial degeneration which can occur during normal aging process, but may be accelerated by other conditions, such as hypertension, bicuspid aortic valve, and genetic changes. Recent advances in the genetic and molecular mechanisms underlying TAA demonstrated a strong genetic component, and several classes of genes responsible for 
TAA have been identified [3]. Certain dietary factors have an impact on the risk of developing an aneurysm, including highcholesterol diet, fatty meat, alcohol consumption, inadequate intake of nuts, fruits, and vegetables. Smoking cigarettes also has a negative effect [2].

The role of copper $(\mathrm{Cu})$ in the human body is connected to its participation in the structures and functions of many enzymes. The function of $\mathrm{Cu}$ in the inflammation process has not been exactly defined. However, the most important is the control of synthesis of free oxygen radicals, due to the presence of this element in $\mathrm{Cu} / \mathrm{Zn}$ - superoxide dismutase. $\mathrm{Cu}$ plays an important role in the synthesis of collagen and elastin. The lysyl oxidase is a Cu-dependent extracellular enzyme which catalyzes formation of aldehydes from lysine residues in elastin and collagen precursors. The changes in the content of $\mathrm{Cu}$ in the arterial wall are important because deficiency of this mineral component may impair the formation of crosslinks in elastin and collagen molecules and lead to the weakening of the resilient properties of elastin and mechanical resistance of collagen [4]. However, an excess $\mathrm{Cu}$, with a simultaneous deficiency of zinc $(\mathrm{Zn})$, can lead to oxidative stress and the formation of an inflammatory process [5]. $\mathrm{Zn}$ is one of the most important trace elements in the human body. This mineral component takes part in over 300 enzymatic reactions and is essential for DNA synthesis, RNA transcription, activation, and cell division. $\mathrm{Zn}$ plays an important role in wound healing, biosynthesis, and homeostasis of connective tissue [6, 7]. As a component of $\mathrm{Cu} / \mathrm{Zn}$, superoxide dismutase $\mathrm{Zn}$ has an antioxidant and anti-inflammatory activity obviously regulating pathogenesis of the inflammation-related diseases [8-10]. Zinc also plays a key role in regulating the function of gelatinases MMP-2 and MMP-9, the group of zincdependent matrix metalloproteinases (MMP), whose expression increases during inflammation with artery damage [11]. Selenium (Se) is a trace element necessary for the proper functioning of the body, but its excess also has negative effects. Se is a component of the active center of glutathione peroxidases (GPXs). Due to reaction with peroxides, Se prevents the body against harmful effects of free radicals, and therefore, it has antioxidant and anti-inflammatory properties $[12,13]$. Se also has a detoxifying effect in the case of exposure to toxic elements, such as lead $(\mathrm{Pb})$ and cadmium $(\mathrm{Cd})$ [14]. Cadmium $(\mathrm{Cd})$ and lead $(\mathrm{Pb})$ are toxic elements, taken from drinking water and food. After absorption into the blood, $\mathrm{Cd}$ and $\mathrm{Pb}$ may accumulate in the liver, kidney, brain, and bone. $\mathrm{Cd}$ has a negative effect on the activity of oxidases and induces lipid peroxidation [15]. Chronic exposure to $\mathrm{Cd}$ can cause cardiovascular diseases. $\mathrm{Cd}$ accumulates in the liver and kidney in the form associated with metallothionein. It is considered that $\mathrm{Cd}$ can affect the development of hypertension, which is probably related to insufficient renin release from the hypoxic kidney, which accumulates large amounts of metallothionein [16]. One of the main toxic effects of $\mathrm{Pb}$ is inhibition of hemoglobin synthesis and a negative influence on the functioning of the circulatory system. With chronic exposure, kidneys and liver may also be damaged $[17,18]$. $\mathrm{Pb}$ may induce oxidative stress and is considered as a potential immunotoxic factor [19]. Oxidative stress has been suggested to play a key role in the pathogenesis of AAA $[20,21]$. However, only few studies have been conducted to evaluate the oxidative stress status of AAA patients. Some studies reported imbalance of mineral components in patients with aneurysms [22-25].

The objective of this study was to estimate the content of microelements: copper $(\mathrm{Cu})$ zinc $(\mathrm{Zn})$, selenium $(\mathrm{Se})$ and toxic elements: cadmium $(\mathrm{Cd})$, lead $(\mathrm{Pb})$ in the tissue of patients with aneurysms. Molar ratio of $\mathrm{Cu} / \mathrm{Zn}$ and antioxidant micronutrients to toxic elements was also assessed.

\section{Material and Methods}

\section{Characteristic of the Examined Groups}

A total of 108 patients: 47 with abdominal aortic aneurysm AAA (41 men and 6 women, aged 46-86, with a mean age of $69.7 \pm 9.9$ years) and 61 patients with thoracic aortic aneurysm TAA (41 men and 20 women, aged $22-83$, with a mean age of $60.1 \pm 13.6$ years), and a control group of 20 abdominal aortic (AA) and thoracic aortic (TA) wall samples from the deceased (aged 21-68, with a mean age of $52.4 \pm 14.5$ years) were studied. Normal aortas were collected from people fatal casualties of traffic accidents, not suffering from chronic diseases such as diabetes and cardiovascular diseases. The size of aneurysm was assessed by ultrasound method. Eighty-seven percent AAA and 79\% TAA patients smoked cigarettes (2040 a day). Forty-five percent of patients with AAA and $15 \%$ patients with TAA declared drinking alcohol (vodka) more than once a week in amount 50-100 g. Patients and control group data are shown in Table 1.

\section{Collection of Samples}

Aneurysmal and control samples were taken during aneurysmectomy and autopsy, respectively, then were frozen at $-80{ }^{\circ} \mathrm{C}$ in the polypropylene tubes. The protocol of the study was approved by the Local Ethical Committee (R-I002/401/2013).

\section{Sample Preparation and Determination of Mineral Components}

Samples weighing approximately $0.3 \mathrm{~g}$ (with the accuracy of $1 \mathrm{mg}$ ) were digested in the concentrated nitric acid using the microwave mineralizer (Berghof, Germany). After the procedure, the samples were quantitatively transferred to 
Table 1 Characteristic of the examined groups

\begin{tabular}{llll}
\hline Variable & Control group & AAA patients & TAA patients \\
\hline Total & 20 & 47 & 61 \\
Gender (M/F) & $(10 / 10)$ & $(41 / 6)$ & $(41 / 20)$ \\
Age (years): average \pm SD (range) & $52.4 \pm 14.5(21-68)$ & $69.7 \pm 9.9(46-86)$ & $60.1 \pm 13.6(22-83)$ \\
Aneurysm size (mm) average \pm SD (range) & - & $73.815 \pm 18.47(50-120)$ & $53.377 \pm 8.56(30-92)$ \\
Smoking cigarettes /no-smoking & nd & $41 / 6$ & $48 / 13$ \\
Alcohol drinking/no-drinking & nd & $21 / 26$ & $9 / 52$ \\
\hline
\end{tabular}

$A A A$ abdominal aortic aneurysm, $T A A$ thoracic aortic aneurysm, $S D$ standard deviation, $n d$ no data

a $20-40$ cigarettes/daily

${ }^{\mathrm{b}}$ More than once a week

polypropylene vessels (20-fold dilution) with ultrapure water. The concentrations of mineral components in the tissue samples were determined by the flame $(\mathrm{Cu}, \mathrm{Zn})$ and the electrothermal $(\mathrm{Se}, \mathrm{Cd}, \mathrm{Pb})$ atomic absorption spectrometry method with the Zeeman background correction (Z-2000 instrument, Hitachi, Japan). The assessments were performed in triplicate. Certified reference material-bovine muscle BCR 184 (Commission of the European Communities, Community Bureau of Reference BCR, Brussels) was used to test the accuracy of the methods. The results of the quality control analyses corresponded with the reference values. The recovery for analytical methods used in estimation of $\mathrm{Cu}, \mathrm{Zn}, \mathrm{Se}$, $\mathrm{Cd}$, and $\mathrm{Pb}$ was $101 \%, 98.5 \%, 97.5 \%, 103 \%$, and $102.5 \%$, respectively. The Department of Bromatology, Medical University of Bialystok participates in a quality control program for trace element analysis supervised by the National Institute of Public Health-National Institute of Hygiene and the Institute of Nuclear Chemistry and Physics. Molar ratio of $\mathrm{Cu} / \mathrm{Zn}$ and antioxidant micronutrients to toxic elements was calculated using Microsoft Excel software.

\section{Statistical Analysis}

Statistical analyses were performed using Statistica v.12.0 software. Data were tested for normal distribution by the Kolmogorov-Smirnov and the Shapiro-Wilk tests. Differences between independent groups were tested by the nonparametric Mann-Whitney $U$ test. Correlation was calculated and tested by Spearman rank test.

\section{Results}

\section{The Concentration of Antioxidant Microelements}

The average concentration of $\mathrm{Cu}$ in the aortic wall of patients with TAA was $1.04 \pm 0.32 \mu \mathrm{g} / \mathrm{g}$ and was significantly lower $(p<0.02)$ than the content of $\mathrm{Cu}$ in the aortic wall samples of healthy people: $1.19 \pm 0.25 \mu \mathrm{g} / \mathrm{g}$. In addition, smokers had a significantly lower $(p<0.04)$ concentration of $\mathrm{Cu}$ in the aneurysmal tissue, compared with non-smokers, $0.985 \pm 0.22 \mu \mathrm{g} / \mathrm{g}$ vs. $1.314 \pm 0.52 \mu \mathrm{g} / \mathrm{g}$. Data are not shown in Table 2. The average content of $\mathrm{Cu}$ in the arterial wall of patients with AAA was $2.15 \pm 1.39 \mu \mathrm{g} / \mathrm{g}$ and did not significantly differ $(p=0.773)$ from the concentration of $\mathrm{Cu}$ in arterial wall samples of healthy people: $1.75 \pm 0.69 \mu \mathrm{g} / \mathrm{g}$.

The mean concentration of $\mathrm{Zn}$ in the aortic wall of patients with TAA and AAA $(12.9 \pm 4.05 \mu \mathrm{g} / \mathrm{g}, 18.54 \pm 12.3 \mu \mathrm{g} / \mathrm{g}$, respectively) was significantly lower $(p<0.05)$ than in the control group samples: $14.71 \pm 2.64 \mu \mathrm{g} / \mathrm{g}, 29.9 \pm 18.88 \mu \mathrm{g} /$ g, respectively (Table 2 ).

We observed a significant correlation between concentration of $\mathrm{Cu}$ and $\mathrm{Zn}$ in the arterial wall samples of patients with TAA and AAA $(r=0.601, p<0.005 ; r=0.477, p<0.05$, respectively). We did not found significant correlations between other determined elements. Data are not presented in tables.

$\mathrm{Cu} / \mathrm{Zn}$ ratio was significantly higher in AAA patients than in control group.

The concentration of Se was significantly decreased in TAA patients compared with the control group $(216.6 \pm$ $64.23 \mathrm{ng} / \mathrm{g}$ vs. $234.14 \pm 32.32 \mathrm{ng} / \mathrm{g}$ ) (Table 2).

The average size of aneurysm in AAA patients was $73.8 \pm$ $18.5 \mathrm{~mm}$ and in TAA patients: $53.4 \pm 8.6 \mathrm{~mm}$. We did not observe any correlations between the size of aneurysms and the concentration of examined microelements.

\section{The Concentration of Toxic Elements}

The content of $\mathrm{Pb}$ was increased $(p<0.05)$ in TAA patients $(366.55 \pm 238.2 \mathrm{ng} / \mathrm{g}$ vs. $251.91 \pm 126.76 \mathrm{ng}$ in the control samples). The concentration of $\mathrm{Cd}$ in aneurysmal wall of both types of aneurysm was similar to normal aortas (Table 2).

We did not find correlations between content of toxic elements and the size of aneurysms. 
Molar Ratio of Antioxidant Micronutrients to Toxic Elements

We observed significantly $(p<0.05)$ lower median $\mathrm{Zn} / \mathrm{Pb}$ ratio in both types of aneurysms (AAA: 321.9, Q1-Q3: 196.1-681.7; TAA: 133.1, Q1-Q3: 80.1-192.3) comparing with control samples (AA: 576.7, Q1-Q3: 380.6-791.5; TA: 215.6, Q1-Q3: 125.5-313.6). The median $\mathrm{Cu} / \mathrm{Pb}$ ratio was significantly lower in TAA patients (11.05, Q1-Q3: 6.6916.76) than in control group (17.73, Q1-Q3: 12.06-23.04). Data are shown on Fig. 1. Additionally in patients who declared frequent alcohol consumption (vodka), the median $\mathrm{Cu} /$ $\mathrm{Pb}$ ratio was significantly lower $(p<0.05)$ compared with non-drinkers (7.5, Q1-Q3: $4.5-11.2$ vs. 12.0, Q1-Q3: 8.119.2). Smoking cigarettes did not affect the molar ratios between the antioxidant micronutrients and toxic elements in both types of aneurysms. Data are not shown on figure.

\section{Discussion}

Imbalance in the concentration of mineral components in the human body is regarded as one of the risk factors for cardiovascular diseases. Our results showed that in patients with TAA, the concentration of $\mathrm{Cu}$ in aortic samples is significantly lower, but in AAA patients, it is comparable with normal aorta. Hunter et al. stated elevated concentration of $\mathrm{Cu}$ in AA tissue samples, especially in hypertensive patients [26]. The biochemical mechanisms by which hypertension accelerates atherosclerosis and increases the risk of rupture AA are poorly understood. AA patients with hypertension had significantly lower zinc levels in aorta samples. Also, $\mathrm{Cu} / \mathrm{Zn}$ superoxide dismutase activity was similarly reduced in the same group of patients. Lower amounts of collagen and elastin in aortas of patients with hypertension were also shown. The authors suggested that the reduction of collagen and elastin in aorta of hypertensive patients with AA compared with their normotensive counterparts may explain the larger size of aneurysms and predispose to eventual rupture. In addition, the diminished antioxidant status associated with hypertension predisposes to lipid peroxidation, which contributes to the acceleration of atherosclerosis processes and risk of rupture AA [26].

Iskra et al. suggested that patients with AAA have deficiency of $\mathrm{Cu}$ in the tissue [22]. Studies of Senapati et al. were not consistent with this observation but showed a lower concentration of $\mathrm{Zn}$ in comparison with normal aortic wall samples. These studies were limited to a small number of examined patients [27]. In our study, the concentration of $\mathrm{Zn}$ was significantly lower in both types of aneurysm compared with normal aortas. Chronic inflammation and degradation of elastin are the main processes in the development of AAA. Recent studies show that $\mathrm{Zn}$ has an anti-inflammatory effect [28]. 

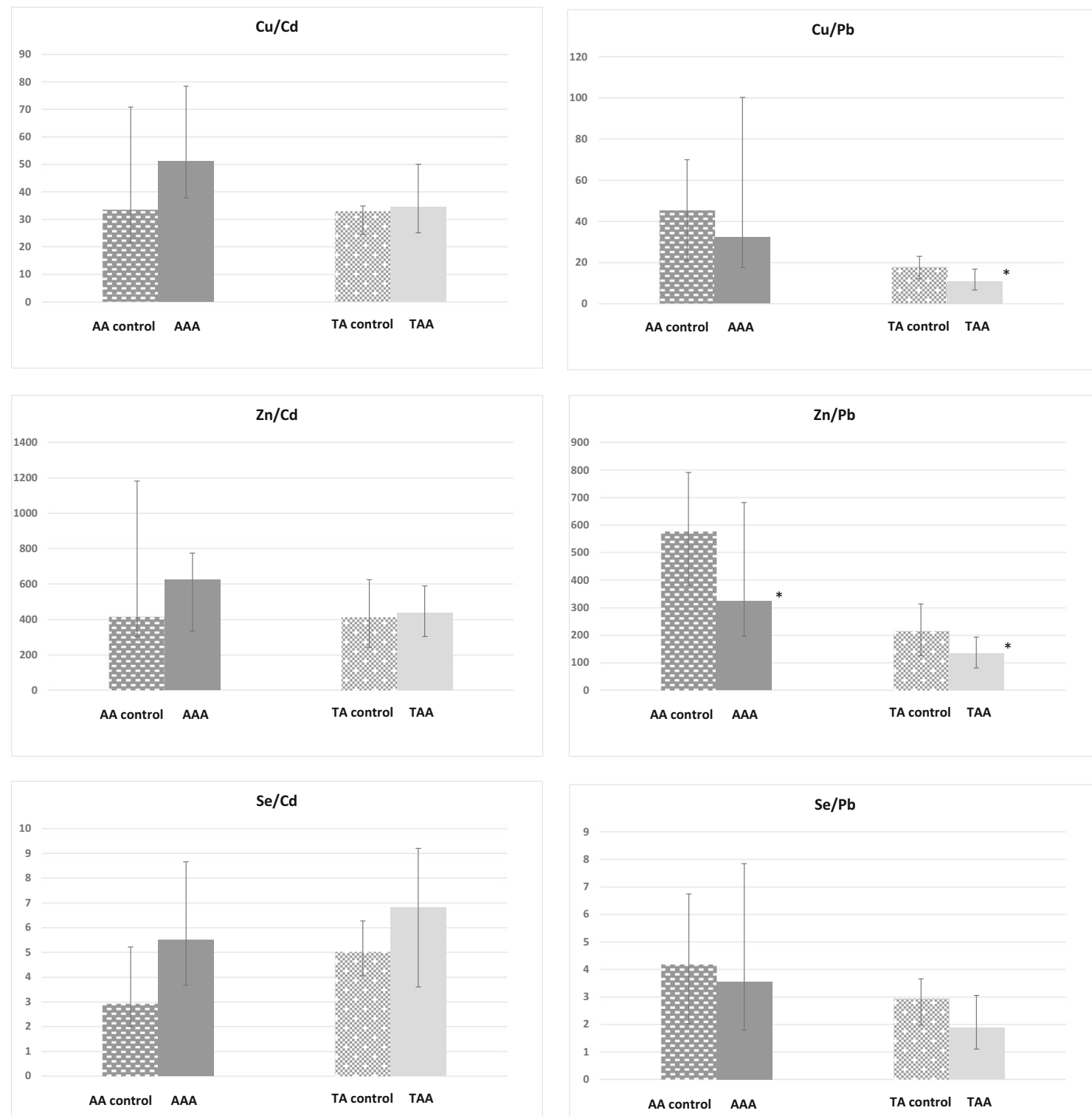

Fig. 1 Molar ratio between antioxidant components and toxic elements in tissue samples of aortic aneurysms and in the control samples. Median values with lower and upper quartiles, AA-abdominal aorta, AAA-abdominal aortic aneurysm, TA-thoracic aorta, TAA-thoracic aortic aneurysm, ${ }^{*} p<0.05$

Based on these, diet supplementation with $\mathrm{Zn}$ may prove to be an effective adjuvant therapy for the treatment of the AAA. Zinc finger protein A20, a zinc-finger transactivating factor, was identified as a primary response gene following inflammatory stimulation of human umbilical vein endothelial cells [29]. A20 can also be induced in smooth muscle cells and exhibit an anti-inflammatory impact by blockade of nuclear factor $\kappa B(N F-k B)$ signaling $[30,31]$. NF- $k B$ can promote chronic inflammation in the aortic wall [32] and regulate MMP transcription [33]. In human and animal experiments, inhibition of NF- $\mathrm{KB}$ activation can prevent the development of AAA [34, 35]. Yan et al. studied the effects of $\mathrm{Zn}$ on AAA progression and its related molecular mechanism. The results showed that Zn supplementation significantly suppressed the abdominal aortic diameter, as well as a preserved medial elastin fibers in the aortas. Zn supplementation also attenuated infiltration of the macrophages and lymphocytes in the aortas. Furthermore, $\mathrm{Zn}$ reduced MMP-2 and MMP-9 production in the aortas and significantly induced A20 protein expression by inhibiting inflammation, along with inhibition of the NF- $\mathrm{KB}$ canonical signaling pathway in vitro in aortic vascular smooth muscle cells and in vivo in rat AAA. This study showed that $\mathrm{Zn}$ supplementation could prevent the development of rat experimental AAA [36]. However, studies of Ziaja et al. have shown that intraluminal thrombus thickness is not associated with a lower concentration of trace elements in the wall of infrarenal AAA [37]. Koksal et al. compared the concentration of $\mathrm{Cu}$ and $\mathrm{Zn}$ in tissues of patients with AAA and aortic 
occlusive disease (AOD). The comparison of tissue $\mathrm{Zn}$ levels showed no significant difference. Tissue levels of $\mathrm{Cu}$ and thiobarbituric acid reactive substances levels, as a marker of lipid peroxidation, were found to be higher in the AAA group, compared with the AOD group. These results suggest that higher oxidative stress in the AAA, compared with AOD, may be one of the factors contributing to the formation of aneurysms as a result of promoted erosion of the walls [23].

Oxidative stress has been suggested to play a key role in the pathogenesis of AAA $[20,21]$. In our study $\mathrm{Cu} / \mathrm{Zn}$ ratio was significantly higher only in AAA patients in comparison with the control group which indicates a greater role of oxidative stress thusly indicating inflammatory process in this type of aneurysm, than in TAA. Edvinsson et al. examined trace element changes in thoracic aortic dissection. They showed decreased concentrations of $\mathrm{Zn}$ and $\mathrm{Cu}$ in tissue compared with the control samples. The $\mathrm{Cu} / \mathrm{Zn}$ ratio in the serum, a marker of infection/inflammation, did not change among patients. These data did not support the hypothesis that inflammation is involved in the pathogenesis of thoracic aortic dissection [25]. Studies of Pincemail et al. showed a significant decrease of plasma levels of $\mathrm{Zn}$ and $\mathrm{Se}$, as AAA size increased. Also, $\mathrm{Cu} /$ $\mathrm{Zn}$ ratio, which is considered as a specific marker of lipid peroxidation, increased, when the size of AAA was higher [38]. In our research, we did not find any correlations between the concentration of the examined elements and the size of aneurysms.

The tissue injury following ischemia-reperfusion is mediated in part by free oxygen radicals. However, studies of Watters et al. suggested that perioperative supplementation with micronutrients with antioxidant properties, such as $\mathrm{Zn}$ and Se, has limited effects on strength and physical function after abdominal aortic aneurysmectomy [39]. We showed that the concentration of Se in aortic samples was significantly lower only in TAA patients. An inadequate Se level is supposed to be a risk factor for cardiovascular diseases. European soil, particularly in Central Europe, is relatively low in this micronutrient, which results in low Se content in food [40]. The decreased plasma Se levels have been associated in European populations with development of different cardiovascular diseases, including AAA in the Polish population. In addition to nutritional Se deficiency, cigarette smoking, the most important risk factor for AAA, may substantially contribute to the reduction of Se levels in patients [41]. Studies of Strauss et al. showed the potential role of the selenoprotein $P$ in pathogenesis of AAA. This study provided preliminary genetic evidence that the SEPP1 functional variants contribute to the AAA risk. The results suggest that the rs3877899A allele may increase the susceptibility or promote AAA progression through influencing the risk of peripheral atherosclerosis and isolated systolic hypertension. The SEPP1 rs3877899G-rs7579G haplotype seems to be a factor that increases predisposition to AAA in overweight and obese patients and a potential marker of aggressive-growing AAAs [42]. It should be remembered that in the case of Se, the safety margin between the recommended and the toxic dose is narrow; therefore, supplementation should be preceded by a biochemical examination [43].

We observed significantly higher concentration of $\mathrm{Pb}$ in aneurysmal wall of TAA patients. Additionally, we found disturbed proportions between $\mathrm{Cu}$ and $\mathrm{Pb}$ in TAA and $\mathrm{Zn}$ and $\mathrm{Pb}$ in both types of aneurysm, while concentration of $\mathrm{Cd}$ is similar to normal aortas in both types of aneurysm. Other studies have shown that the elevated levels of $\mathrm{Cd}$ in the walls of AAA coexisting with iliac artery aneurysms may suggest an impact on the accumulation of this toxic element and greater damage of the iliac artery wall [24].

\section{Conclusions}

In the examined aneurysms, we have shown the differences in concentrations of mineral components compared with the control tissues. The $\mathrm{Zn}$ concentration was decreased in both AAA and TAA samples. Impaired ratio of $\mathrm{Zn}$ to $\mathrm{Pb}$ may predispose to aortic aneurysms. Further work is required to confirm obtained findings.

Authors' Contributions Conceptualization, KS.; methodology and investigation, K. S, A.K. and R.M-Ż.; formal analysis, K. S, A.K., R.M-Ż., and A.K.; resources, $\mathrm{AG}, \mathrm{MG}$, and $\mathrm{TH}$; writing original draft preparation, $\mathrm{K}$. S, A.K., R.M-Ż., and A.K.; supervision, K. S, A.K., R.M-Ż., A.K., and M.H.B. All authors have read and agreed to the published version of the manuscript.

Funding The study was supported by a grant from Polish Ministry of Science and High Education N/ST/ZB/17/002/2216 and N/ST/ZB/16/ $005 / 2216$.

\section{Compliance with Ethical Standards}

Conflict of Interest The authors declare that they have no conflict of interest.

Disclaimer The funders had no role in the design of the study; in the collection, analyses, or interpretation of data; in the writing of the manuscript or in the decision to publish the results.

Open Access This article is licensed under a Creative Commons Attribution 4.0 International License, which permits use, sharing, adaptation, distribution and reproduction in any medium or format, as long as you give appropriate credit to the original author(s) and the source, provide a link to the Creative Commons licence, and indicate if changes were made. The images or other third party material in this article are included in the article's Creative Commons licence, unless indicated otherwise in a credit line to the material. If material is not included in the article's Creative Commons licence and your intended use is not permitted by statutory regulation or exceeds the permitted use, you will need to obtain permission directly from the copyright holder. To view a copy of this licence, visit http://creativecommons.org/licenses/by/4.0/. 


\section{References}

1. Ladich E, Yahagi K, Romero ME, Virmani R (2016) Vascular diseases: aortitis, aortic aneurysms, and vascular calcification. Cardiovasc Pathol 25(5):432-441. https://doi.org/10.1016/j. carpath.2016.07.002

2. Kent KC, Zwolak RM, Egorova NN, Riles TS, Manganaro A, Moskowitz AJ, Gelijns AC, Greco G (2010) Analysis of risk factors for AAaneurysm in a cohort of more than 3 million individuals. $\mathrm{J}$ Vasc Surg 52(3):539-548. https://doi.org/10.1016/j.jvs.2010.05. 090

3. Halushka MK (2012) Single gene disorders of the aortic wall. Cardiovasc Pathol 21(4):240-244. https://doi.org/10.1016/j. carpath.2011.09.004

4. López B, González A, Hermida N, Valencia F, de Teresa E, Díez J (2010) Role of lysyl oxidase in myocardial fibrosis: from basic science to clinical aspects. Am J Physiol Heart Circ Physiol 299(1):H1-H9. https://doi.org/10.1152/ajpheart.00335.2010

5. Guo CH, Wang CL (2013) Effects of zinc supplementation on plasma copper/zinc ratios, oxidative stress, and immunological status in hemodialysis patients. Int J Med Sci 10(1):79-89. https://doi. org/10.7150/ijms.5291

6. Rink L, Gabriel P (2000) Zinc and the immune system. Proc Nutr Soc 59(4):541-552

7. Bhowmik D, Chiranjib KP, Kumar KPS (2010) A potential medicinal importance of zinc in human health and chronic disease. Int $\mathrm{J}$ Pharm Biomed Sci 1(1):5-11

8. Rahman K (2007) Studies on free radicals, antioxidants, and cofactors. Clin Interv Aging 2(2):219-236

9. Prasad AS (2009) Zinc: role in immunity, oxidative stress and chronic inflammation. Curr Opin Clin Nutr Metab Care 12(6): 646-652. https://doi.org/10.1097/MCO.0b013e3283312956

10. Bao B, Prasad AS, Beck FW, Fitzgerald JT, Snell D, Bao GW, Singh T, Cardozo LJ (2010) Zinc decreases C-reactive protein, lipid peroxidation, and inflammatory cytokines in elderly subjects: a potential implication of zinc as an atheroprotective agent. Am J Clin Nutr 91(6):1634-1641. https://doi.org/10.3945/ajen.2009.28836

11. Löffek S, Schilling O, Franzke CW (2011) Biological role of matrix metalloproteinases: a critical balance. Eur Respir J 38(1):191-208

12. Brenneisen P, Steinbrenner H, Sies H (2005) Selenium, oxidative stress, and health aspects. Mol Asp Med 26(4-5):256-267

13. Rayman MP (2005) Selenium in cancer prevention: a review of the evidence and mechanism of action. Proc Nutr Soc 64(4):527-542

14. Tchounwou PB, Yedjou CG, Patlolla AK, Sutton DJ (2012) Heavy metals toxicity and the environment. Exp Suppl 101:133-164. https://doi.org/10.1007/978-3-7643-8340-4_6

15. Jaishankar M, Tseten T, Anbalagan N, Mathew BB, Beeregowda KN (2014) Toxicity, mechanism and health effects of some heavy metals. Interdiscip Toxicol 7(2):60-72. https://doi.org/10.2478/ intox-2014-0009

16. Rafati Rahimzadeh M, Rafati Rahimzadeh M, Kazemi S, Moghadamnia AA (2017) Cadmium toxicity and treatment: an update. Caspian J Intern Med 8(3):135-145. https://doi.org/10. 22088/cjim.8.3.135

17. Flora G, Gupta D, Tiwari A (2012) Toxicity of lead: a review with recent updates. Interdiscip Toxicol 5(2):47-58. https://doi.org/10. 2478/v10102-012-0009-2

18. Wani AL, Ara A, Usmani JA (2015) Lead toxicity: a review. Interdiscip Toxicol 8(2):55-64. https://doi.org/10.1515/intox2015-0009

19. Fenga C, Gangemi S, di Salvatore V, Falzone L, Libra M (2017) Immunological effects of occupational exposure to lead (review). Mol Med Rep 15(5):3355-3360. https://doi.org/10.3892/mmr. 2017.6381
20. Paraskevas KI (2018) Aortic wall inflammation: a more accurate predictor of aneurysm expansion and aneurysm rupture risk than aortic diameter? J Thorac Dis 10(Suppl 33):S3865-S3866. https:// doi.org/10.21037/jtd.2018.09.36

21. Brittenden J, Houston G, Lambie R, Norrie J, McBride O, Forsythe R, Newby D, McKillop G, Semple S, Burns P, Berry C, Murray G, Wee F (2017) Aortic wall inflammation predicts abdominal aortic aneurysm expansion, rupture, and need for surgical repair. Circulation 136(9):787-797. https://doi.org/10.1161/ CIRCULATIONAHA.117.028433

22. Iskra M, Patelski J, Majewski W (1997) Relationship of calcium, magnesium, zinc and copper concentrations in the arterial wall and serum in atherosclerosis obliterans and aneurysm. $\mathrm{J}$ Trace Elem Med Biol 11(4):248-252

23. Koksal C, Ercan M, Bozkurt AK, Cortelekoglu T, Konukoglu D (2007) Abdominal aortic aneurysm or aortic occlusive disease: role of trace element imbalance. Angiology 58(2):191-195. https://doi. org $/ 10.1177 / 0003319707300354$

24. Ziaja D, Chudek J, Sznapka M, Kita A, Biolik G, Sieroń-Stołtny K, Pawlicki K, Domalik J, Ziaja K (2015) Trace elements in the wall of abdominal aortic aneurysms with and without coexisting iliac artery aneurysms. Biol Trace Elem Res 165(2):119-122. https://doi.org/ 10.1007/s12011-015-0240-8

25. Edvinsson M, Ilbäck NG, Frisk $P$, Thelin S, Nyström-Rosander C (2016) Trace element changes in thoracic aortic dissection. Biol Trace Elem Res 169(2):159-163. https://doi.org/10.1007/s12011015-0432-2

26. Hunter GC, Dubick MA, Keen CL, Eskelson CD (1991) Effects of hypertension on aortic antioxidant status in human abdominal aneurysmal and occlusive disease. Proc Soc Exp Biol Med 196(3): 273-279

27. Senapati A, Carlsson LK, Fletcher CD, Browse NL, Thompson RP (1985) Is tissue copper deficiency associated with aortic aneurysms? Br J Surg 72(5):352-353. https://doi.org/10.1002/bjs. 1800720507

28. Jarosz M, Olbert M, Wyszogrodzka G, Młyniec K, Librowski T (2017) Antioxidant and anti-inflammatory effects of zinc. Zincdependent NF-KB signaling. Inflammopharmacology 25(1):1124. https://doi.org/10.1007/s10787-017-0309-4

29. Verstrepen L, Verhelst K, van Loo G, Carpentier I, Ley SC, Beyaert R (2010) Expression, biological activities and mechanisms of action of A20 (TNFAIP3). Biochem Pharmacol 80(12):2009-2020. https://doi.org/10.1016/j.bcp.2010.06.044

30. Beyaert R, Heyninck K, Van Huffel S (2000) A20 and A20-binding proteins as cellular inhibitors of nuclear factor- $\mathrm{KB}$-dependent gene expression and apoptosis. Biochem Pharmacol 60(8):1143-1151. https://doi.org/10.1016/s0006-2952(00)00404-4

31. Damrauer SM, Fisher MD, Wada H, Siracuse JJ, da Silva CG, Moon K, Csizmadia E, Maccariello ER, Patel VI, Studer P, Essayagh S, Aird WC, Daniel S, Ferran C (2010) A20 inhibits post-angioplasty restenosis by blocking macrophage trafficking and decreasing adventitial neovascularization. Atherosclerosis 211(2):404-408. https://doi.org/10.1016/j.atherosclerosis.2010.03. 029

32. Mi T, Nie B, Zhang C, Zhou H (2011) The elevated expression of osteopontin and NF- $\mathrm{kB}$ in human aortic aneurysms and its implication. J Huazhong Univ Sci Technolog Med Sci 31(5):602-607. https://doi.org/10.1007/s1 1596-011-0568-Z

33. Chase AJ, Bond M, Crook MF, Newby AC (2002) Role of nuclear factor- $\mathrm{KB}$ activation in metalloproteinase- $1,-3$, and -9 secretion by human macrophages in vitro and rabbit foam cells produced in vivo. Arterioscler Thromb Vasc Biol 22(5):765-771

34. Nakashima H, Aoki M, Miyake T, Kawasaki T, Iwai M, Jo N, Oishi M, Kataoka K, Ohgi S, Ogihara T, Kaneda Y, Morishita R (2004) Inhibition of experimental abdominal aortic aneurysm in the rat by use of decoy oligodeoxynucleotides suppressing activity of nuclear 
factor kappaB and ets transcription factors. Circulation 109(1):132138. https://doi.org/10.1161/01.CIR.0000105725.61763.A2

35. Miyake T, Aoki M, Nakashima H, Ka T (2006) Prevention of abdominal aortic aneurysms by simultaneous inhibition of NFkappaB and ets using chimeric decoy oligonucleotides in a rabbit model. Gene Ther 13(8):695-704. https://doi.org/10.1038/sj.gt. 3302704

36. Yan YW, Fan J, Bai SL, Hou WJ, Li X, Tong H (2016) Zinc prevents abdominal aortic aneurysm formation by induction of A20-mediated suppression of NF-kB pathway. PLoS One 11(2): e0148536. https://doi.org/10.1371/journal.pone.0148536 eCollection 2016

37. Ziaja D, Kita A, Janowska J, Pawlicki K, Mikuła B, Sznapka M, Chudek J, Ziaja K (2014) Intraluminal thrombus thickness is not related to lower concentrations of trace elements in the wall of infrarenal abdominal aortic aneurysms. J Trace Elem Med Biol 28(1):28-31. https://doi.org/10.1016/j.jtemb.2013.09.007

38. Pincemail J, Defraigne JO, Cheramy-Bien JP, Dardenne N, Donneau AF, Albert A, Labropoulos N, Sakalihasan N (2012) On the potential increase of the oxidative stress status in patients with abdominal aortic aneurysm. Redox Rep 17(4):139-144. https://doi. org/10.1179/1351000212Y.0000000012
39. Watters JM, Vallerand A, Kirkpatrick SM, Abbott HE, Norris S, Wells G, Barber GG (2002) Limited effects of micronutrient supplementation on strength and physical function after abdominal aortic aneurysmectomy. Clin Nutr 21(4):321-327

40. Wasowicz W, Gromadzinska J, Rydzynski K, Tomczak J (2003) Selenium status of low-selenium area residents: Polish experience. Toxicol Lett 137(1-2):95-101

41. Socha K, Borawska MH, Gacko M, Guzowski A (2011) Diet and the content of selenium and lead in patients with abdominal aortic aneurysm. Vasa 40(5):81-89. https://doi.org/10.1024/0301-1526/ a000135

42. Strauss E, Oszkinis G, Staniszewski R (2014) SEPP1 gene variants and abdominal aortic aneurysm: gene association in relation to metabolic risk factors and peripheral arterial disease coexistence. Sci Rep 4:7061. https://doi.org/10.1038/srep07061

43. Aldosary BM, Sutter ME, Schwartz M, Morgan BW (2012) Case series of selenium toxicity from a nutritional supplement. Clin Toxicol (Phila) 50(1):57-64. https://doi.org/10.3109/15563650. 2011.641560

Publisher's Note Springer Nature remains neutral with regard to jurisdictional claims in published maps and institutional affiliations. 